\title{
On the transcendental undercurrents of phenomenology: the case of the living body
}

\author{
Sara Heinämaa ${ }^{1}$
}

Accepted: 3 February 2021 / Published online: 27 May 2021

(C) The Author(s) 2021

\begin{abstract}
Today the phenomenological concept of the lived body figures centrally in several philosophical and special scientific debates. In these wide and widening fields, the concept is used with multiple different meanings. In order to clarify and delineate the debates, this paper provides an explication of the phenomenological-transcendental methods. It argues that these methods help us remove the most fundamental ambiguities of the concept of embodiment by distinguishing between the main constituents of the lived body and by illuminating their mutual relations.
\end{abstract}

Keywords Constitution · Lived body $($ Leib) $\cdot$ Reduction $\cdot$ Transcendental phenomenology $\cdot$ Husserl $\cdot$ Merleau-Ponty

Today the phenomenological concept of the lived body figures centrally in several philosophical and special scientific debates, from the medical sciences to the social and political sciences. Examples of disciplines that use the concept in fruitful new ways include the neurosciences, psychopathology, social psychology, qualitative sociology, political science and critical anthropology. Moreover, the concept also serves several broadly interdisciplinary fields, such as gender studies, race studies, disability studies and nursing studies.

In all these contexts, the concept of the lived body opens philosophical perspectives on human embodiment and phenomena that depend on human embodiment. In some contexts, it helps to clarify the structures of perception and movement, in others it illuminates the nature of human health, vulnerability, suffering, mortality or sexuality, and in still others it elucidates the functions of emotion, communication, action and interaction. Phenomenological analyses of the lived body serve all these thematic fields by demonstrating that the human body is not merely a material being - a physical substance, a bio-chemical organism or a segment of matter-but also a freely moving, expressive and developing power.

Sara Heinämaa

sara.heinamaa@jyu.fi

1 Academy of Finland, University of Jyväskylä, Meritullinkatu 15 D 42, 00170 Helsinki, Finland 
However, in these wide and widening fields, the concept of the lived body has been given several different definitions. Contributors draw directly from classical and existential phenomenological sources in defining the concept. But since these authorities are many and not unanimous, we end up with a variety of definitions, and terminological choices based on them.

To get a preliminary insight into this variance, one only needs to notice that contemporary phenomenological conceptualizations of embodiment draw from Husserl and Merleau-Ponty but often also from Heidegger, Levinas, Sartre, Henry and Plessner. When one realizes that these authors diverged not only in their analyses of sensibility, materiality and thinghood but also in their understanding of the principal tasks of phenomenological inquiries, then it becomes a more complicated affair to talk about a single unified phenomenological approach, since the actual approaches are more scattered than the overarching term "lived body" suggests.

In the following, I will argue that the ambiguities in the terminology and conceptualization of lived embodiment betray fundamental philosophical discrepancies. I believe that the removal of these ambiguities will advance the progress of phenomenological inquiries in all topical areas that deal with human bodies. For this purpose, I will discuss the phenomenological-transcendental method and argue that it allows us to remove the most fundamental ambiguities of the concept of embodiment by distinguishing between diverse constituents of the lived body and their mutual relations.

Before proceeding to the methodological argument, I need to make two clarificatory points. These concern, first, the meanings and connotations of the term "lived body" and, second, the definitions given to this term in contemporary phenomenological literature. Since I believe that terminological and conceptual issues should be kept distinct for systematic purposes, I will handle these two matters separately, beginning with terminological challenges (Sect. 1) and proceeding to discuss the state of the art in conceptualization (Sect. 2). After these clarificatory sections, I will offer an argument about the function of the transcendental, eidetic and abstractive reductions in inquiries that concern the sense of lived embodiment (Sect. 3).

\section{From "lived" to "living"}

In contemporary scholarly discussions, across the fields of the medical, social and human sciences, the term "lived body" serves as the English translation of the technical French terms "corps vécu" and "corps vivant," introduced into phenomenology by the French existentialists in the 1930s and 1940s. These were originally used by Levinas, Sartre and Merleau-Ponty as equivalents and derivatives of the German term "Leib" that figured centrally in Husserl's philosophical discussions of perception and alterity. ${ }^{1}$ Husserl first used the term "Leib" when analyzing the role of the

\footnotetext{
${ }^{1}$ Levinas introduces Husserl's phenomenological account of embodiment at the end of his The Theory of Intuition in Husserl (Levinas [1930] 1963, p. 213ff./149ff.). In Structure of Behavior, Merleau-Ponty begins his discussion of the living body (corps vivant) or, as he also calls it, the phenomenal body (corps phénoménal) in a chapter titled "Vital structures" (Merleau-Ponty 1942, p. 169/156). In Phenomenology of Perception, the discussion of embodiment starts already in the preface with the treatment of facticity,
} 
body in perception and motility, but as his inquiries proceeded and covered new ground, he realized that the term "Leib" was also needed in the analysis of alterity, intersubjectivity and objectivity as well as the fundamental self-objectification of the ego. ${ }^{2}$

So, the English term "lived body" is coined to serve the same philosophical functions as the French term "corps vécu" (and the German term "Leib"), and thus phenomenological inquiries seem to proceed quite seamlessly from Husserl's early analyses to the debates of the French phenomenologists and finally to our contemporary theorization of a great variety of topics.

However, these three translational equivalents- "Leib," "corps vécu" and "lived body"-have very different connotations, partly due to their different positions in everyday language, partly due to their divergent etymologies and partly due to their various syntactic forms. In order to see that conventions of scholarly translation cover over important differences of meaning, we need to take a closer look at the terms.

The German term "Leib" was not a neologism by Husserl but an ordinary word with a wide range of usages. The term derives from the same root as the verb "leben" (to live) and refers to the body as a living, and continuously living, being. It can also be used to refer to the abdomen, the belly, the stomach and the womb, and thus it involves deep connotations of vitality, fertility and persistence, in contrast to illness, barrenness and death. ${ }^{3}$

Husserl, however, redefined the term for his own philosophical purposes and used it coherently to bypass traditional philosophical accounts of embodiment-Platonic, Aristotelian, Cartesian and naturalistic-as well as positive scientific theories of the human body and its relation to the soul (physiological, biological, zoological, psychological). This was his general strategy with language. He was an optimistic realist in respect to our possibilities of changing the meanings of terms and did not believe that we live in a prison house of language or that our expressive possibilities were fixed by the linguistic practices and habits of our predecessors. ${ }^{4}$

The everyday German word "Leib" served Husserl's interests well since it did not suggest any specific relation-oppositional, foundational or functionalbetween mind and body, spirit and matter, psyche and physis, as did the terms "Körper," "organism," "soma" and "substance." His guiding interest was not in grounding anthropology on somatology, but in studying how sense is constituted

\footnotetext{
Footnote 1 (continued)

haecceity and alterity (Merleau-Ponty [1945] 1993, p. vi/xiiff.). Sartre introduces the concept of the lived body (corps vécu) in the phenomenological section of his early essay on emotions (Sartre [1938] 1995, p. $98 \mathrm{ff} . / 75 \mathrm{ff}$.), and again in the second chapter of the third part of Being and Nothingness (Sartre [1943] 1998, pp. 342/401ff., 392/461ff.).

2 Hua16; Hua1; Hua4; Hua6; Hua13; Hua14; Hua15; cf. Behnke ([1989] 1996); Taipale (2009); Heinämaa $(2011 ; 2018)$.

3 Seebold (ed.) (2002, p. 566).

${ }^{4}$ Husserl believed that the meanings of philosophical terms are instituted and fixed, not by their etymological origins or by the earlier uses, but by the systematic roles and functions that we give them in our thinking.
} 
in experience. ${ }^{5}$ In case of the body, the main question concerned the constitutive roles that bodies have in their different senses as well as the relations of dependency between these senses and the grounds on which they are established.

Levinas, Merleau-Ponty and Sartre introduced the French term "corps vécu" for the purpose of referring to the body as a living active being rather than a piece of inanimate matter. Since the modificand of this French term, the word "corps," refers to the material part of the animal and to material things more generally, in opposition to mental and spiritual entities, the modifier "vécu" was needed to add the sense of life and to keep the meant objectivities apart from corpses. The English translation "lived body" follows the same strategy.

As a result, the English "lived body" entails the same complication as the French "corps vécu": in distinction from the German "Leib," both suggest that lived bodies form a subclass of the general class of bodies, and are distinguished from other bodies by the additional property or power of being living. Such a suggestion may be unimportant or trivial in everyday and special scientific contexts but in the framework of phenomenology it complicates matters. This is because phenomenology requires that questions concerning the manner and extent in which living bodies belong among other bodies should not be settled in advance but must be solved by radically unprejudiced inquiries. ${ }^{6}$

The terms "lived body" and "corps vécu" also entail another complication. The participial verbal adjective by which these terms attribute life to bodies is in the past tense. Literally, the body is said to be "lived" rather than "living." This suggests the idea that the power of living belongs to some agent other than the body and is merely lent to the body, either regularly or occasionally. Thus, both terms suggest that the body at issue is lifeless as such and in need of animation by some separate agent. Such connotations are absent from the German "Leib" since the term is not derived from the past participle "gelebt," or from any verbal form: The body itself is living and does not need to borrow this power or activity from any other agent. ${ }^{7}$

The English term "living body" and the French equivalent "corps vivant" avoid the additional difficulty of the terms "lived body" and "corps vécu." Both have the advantage of attributing the power of life directly to the body. For these reasons, I will use the term "living body" in the following argumentation instead of the widespread "lived body." 8 So the term does not here refer to biological organisms or living tissues. It means a specific sense of embodiment central in all experiencing of worldly objectivities (organisms and tissues included) and originally captured by the German "Leib." To determine what this sense entails, however, turns out to be a more complicated task than it may at first seem, and a task that depends also on the methods by which one proceeds.

\footnotetext{
5 Cf. Hua5, pp. 10-21.

6 Cf. Hua4, p. 144/152.

7 Cf. Merleau-Ponty (1964a, pp. 21/163-164).

8 Thus, I follow David Carr, James S. Churchill and Karl Ameriks who translate "Leib" as "living body," and Körper" as "physical body" or "material body," cf. Hua6; Husserl ([1939] 1985).
} 


\section{The personal, the existent, the immanent}

The phenomenological concept of the living body (Leib, corps vivant) is defined in several different ways in contemporary theoretical literature. Alternative definition-strategies provide conceptualizations that are partly overlapping but also entail philosophically crucial differences of emphasis, extension and order of analysis. For systematic purposes, I distinguish between three basic ways of defining the concept: First, definitions that operate by the distinction between the first-person perspective and the third-person perspective; second, definitions that resort to the distinction between being and having (or existing and possessing); and, third, definitions that draw from the distinction between subjectivity and objectivity.

A common and widespread way of defining the concept of the living body is to say that it refers to our own body (der eigene Leib, corps propre) as it appears to us in the first-person perspective. ${ }^{9}$ This distinguishes the living body from all bodies as they appear or are given in the second- and third-person perspectives. The contrasting sense is called either "the objective body" or "the body for others." Thus, one can argue, for example, that the conditions of anorexia and bulimia, or eating disorders more generally, entail a crucial experiential difference between the living body and the objective body or the body as it appears to others. ${ }^{10}$ The body that in the first-person perspective appears as enormous is objectively either normal or reduced in its dimensions. ${ }^{11}$ Similarly, one can argue that transgender experiences are explicable by the conceptual distinction between one's own living body given in the firstperson perspective and the objective body studied in the third-person perspective: The body which in the third-person perspective forms a relatively coherent functional and organic whole is in the first-person perspective experienced as fundamentally alien, distorted or split. ${ }^{12}$

This way of conceptualizing the living body uses the perceptual metaphor of the perspective to distinguish the phenomenological description from the explanatory approaches of the empirical-factual sciences. Moreover, the linguistic determinations "first-person" and "third-person" carry with them the distinction between the singular and the general. Thus, the living body-the body in its first-person givenness - is contrasted both to the body that can be grasped by scientific methods and to the body that is accessible to all subjects equally. ${ }^{13}$

The perspectival articulation of the idea of the living body refers back to Merleau-Ponty's and Husserl's distinctions between two attitudes in which we can study living beings: the objective and the experiential. However, the concept of perspective differs from the phenomenological concept of attitude in one crucial manner: Whereas perspectives are selective, attitudes are more comprehensive ways

\footnotetext{
${ }^{9}$ E.g. Toombs (1988); Leder (1990; 1992); Gallagher (2005); Svenaeus (2015); cf. Fuchs (2005).

${ }^{10}$ E.g. Svenaeus (2013); Castellini et al. (2014); Gaete and Fuchs (2016).

11 E.g. Englebert et al. (2018).

12 E.g. Salomon (2010, p. 43ff); Kondelin (2014); cf. Johnson (2007).

13 In the case of anorexia, for example, the third-person perspective may be represented by medical experts while the second-person perspective may be attributed to the family and/or the therapists.
} 
of relating to things; whereas perspectives study objects from different locations, attitudes give us the whole world in different manners, including all its objects and locations, however diverse these may be. ${ }^{14}$

Thus, we can choose a perspective and alternate between perspectives without effecting any thorough changes in our ways of relating to worldly beings or to the world as a whole. Attitudes too can be changed or alternate but not without largescale effects in our manners of relating. Accordingly, if we adopt the objective or objectifying attitude in respect to our own body, then we are bound to study also other things independently of their experiential (subjective and personal) determinants, but if we, in contrast, take the third-person perspective on our own body, then we may leave other things largely intact and entertain them in second- and firstperson perspectives. Similarly, if we adopt an experiential attitude to our body, then we must study also the environing things in their subjective determinants, but if we instead take the first-person perspective on our own bodies, then most other thingsincluding other bodies - may be given in other perspectives and some of them may be grasped by third-person concepts.

So, when a philosopher or theorist conceptualizes the living body by the contrast between the first-person and the third-person perspectives, then she is able to study the variance of human embodiment without any thorough or large-scale change in her own worldly relations. Her task is to give expression to the first-person experiences of the persons studied, and the main thing to guard against is the usage of scientifically established notions and socially dominant norms of embodiment and the imposition of such ready-made objective notions and norms on the subjects under investigation. $^{15}$

The other common manner of defining the living body utilizes the conceptual distinction between being and having. ${ }^{16}$ The living body is defined as the body that we are in distinction from the body that we have. This conceptualization draws from the analyses of Helmuth Plessner but also from Husserl's distinctions between egoic life and egoic possessions. The main point here is that whereas we can lose, abandon and replace our possessions, we cannot similarly be deprived of our being or existence, or any constitutive parts of it. If the living body is what we are, in distinction from the things and bodies that we have, then we cannot distance ourselves from it or replace it without changing ourselves. Understood in this way, the living body is not a matter of altering perspectives or viewpoints but concerns our very existence.

Two variants of this definition can be distinguished by considering the basic relation of the living body to other bodies. Some contemporary scholars follow Plessner and argue that each of us "is $a$ living body [Leib]." 17 The indefinite form "a body" suggests that our living body is one among many, that is, one among other similar bodies each of which can be identified with some subject or other. However, the basic existential insight can also be formulated by modal language by saying that

\footnotetext{
14 Hua6; Merleau-Ponty ([1945] 1993).

15 Friesen et al. (2012, pp. 38ff., 179ff.); cf. Dahlberg et al. (2001); Dahlberg and Dahlberg (2019).

16 E.g. Lindemann (2010); Wehrle (2020).

17 E.g. Plessner (1970, p. 34); cf. Plessner (1975).
} 
the living body is our manner of having the world. ${ }^{18}$ In this formulation, the possessive pronoun "our" expresses the subject-relative character of embodiment, but the definite form "the world" suggest that this subjective body that I am is not (just) one body among many similar ones but (also) operates as the condition on which I can have the world, and everything entailed in it, all other bodies included.

The third way of defining the living body operates with the distinction between subjectivity and objectivity. The living body is defined as a system or complex of kinaesthetic and tactile sensings (Befindnisse) in functional and motivational connections. ${ }^{19}$ As such the body is a pre-objective form or scheme of subjective experiencing that emerges within the stream of consciousness. It does not appear by means of spatial adumbrations or profiles but establishes its dynamic limits already in affection and self-affection. As Alia Al-Saji puts it, the living body is "surface of touch." 20 Thus understood, kinaesthetic and tactile sensations are not only the necessary constituents of living bodiliness; they are the living body per se in its most "original" pre-objective givenness. ${ }^{21}$

This way of conceptualizing the living body draws from Levinas' and Sartre's critical confrontations with Husserl's account of sensibility. ${ }^{22}$ Some versions of it are also influenced by Michel Henry's Biranian reformulation of classical phenomenology. ${ }^{23}$ Henry's concepts of transcendental affectivity and immanent receptivity suggests the notion that the unity of the lived body is constituted prior to and independently of all objectifying intending. Thus, it becomes possible to argue that all worldly possessions, given in various degrees of familiarity and intimacy, must be kept distinct from "the transcendental body" that coincides with our transcendental life and operates as the foundation of everything worldly. ${ }^{24}$

One crucial implication of this conceptualization is that in its primary form the living body does not have any spatiality and cannot be perceived in the proper sense of the word. This is because all perception proceeds by adumbrations and profiles. In contrast, the living body does not break out from the flow of consciousness but merely marks the contours of subjectivity. So, if one would argue, within this conceptual framework, that anorexia as an experiential condition entails complications in living bodiliness, then one would not restrict these complications to perceptual distortions merely but would rather suggest that they belong to the fundamental level of pre-objective sensibility. Similarly, if one would argue that transgender subjects

\footnotetext{
${ }^{18}$ Merleau-Ponty ([1945] 1993, pp. 402/350, cf. 67-68/55, 369/318-319, 444-445/387-388, 256/221222, 433/378). Cf. Merleau-Ponty's formulation in Phenomenology of Perception: "we have found underneath the objective and detached knowledge of the body that other knowledge which we have of it in virtue of its always being with us and of facts that we are body [nous sommes corps]" (Merleau-Ponty [1945] 1993, pp. 293/206, my italics).

${ }^{19}$ E.g. Gallagher (1986); Welton (1999, pp. 82-83); Al-Saji (2010, pp. 18-20); Sparrow (2015).

${ }^{20}$ Al-Saji (2010, p. 19).

21 "Leiblichkeit" in Husserl, and "corporéité" and "chair" in Merleau-Ponty.

${ }^{22}$ Sartre ([1943] 1998, p. 343ff./402ff.); Levinas ([1959] 1998); and Merleau-Ponty's ([1945] 1993; 1964b) topological conceptualizations of human embodiment.

${ }^{23}$ Cf. Henry (1975; [1990] 2008).

${ }^{24}$ Cf. Taipale (2009, p. 53).
} 
experience their living bodies differently from other subjects, then one would again argue for variance on the level of pre-objective sensibility.

This conceptualization allows for two main variants, one egoic and the other nonegoic. Some contributors argue that even if the living body, understood as a system of pure sensing and motor potentiality, lacks all structures that result from the objectifying acts of intentionality, it still has an egoic form. ${ }^{25}$ Others contend that if we dig through all the strata of objectifying intentionality, then we encounter an anonymous layer of lived-through sensibility and bodily self-awareness free from all egoic forms and structures. Alia Al-Saji formulates this latter conviction by writing: "Sensings [Empfindnisse] give the particular self-awareness that characterizes the lived body at the level prior to its being objectified as mine. It is a tacit bodily awareness that is lived through without self-ascription or objectification." 26 The mineness of the living body would thus be a secondary formation, resulting from a subsequent objectification and thematization that works on the primary system of nonegoic sensings. Thus, if we operate within this conceptual framework and argue that anorectic or transgender experiences involve alterations in living bodiliness, then we do not merely claim that such conditions affect the person's sense of bodily selfhood but also contend that they transform a supposedly deeper level of anonymous embodiment.

All these definitions have their advantages in the analysis of the concrete phenomena of embodiment and the variety of human experience. The problem, however, is that terminological unity hides conceptual variance: contributors often seem to agree-or alternatively disagree-when in truth they are speaking about different matters.

These equivocations of contemporary phenomenological discussions and debates on living bodies have not gone unnoticed. Some critics argue that the main confusion stems from Husserl's original expositions and that it seriously harmed his own account of intersubjectivity and objectivity which he tried to establish on his premature analysis of embodiment.

In "Transcendental phenomenology and the seductions of naturalism," Steven Crowell argues that Husserl's discourse on the living body is fundamentally ambiguous and incoherent. ${ }^{27}$ More precisely, Crowell contends that Husserl uses the term "Leib" in two oppositional senses, on the one hand meaning the constituting body, the body that participates in constitutive activities, and on the other hand the constituted body as part of the (pregiven) world. We read,

Since Husserl does not recognize the ambiguity, he thinks that Leib as organ of my will appears, and can thus provide the basis for an 'apperceptive transfer' thanks to which I recognize other things in my world as [living bodies], thus constituting myself contingently as part of nature (...). But if we suspend

\footnotetext{
25 E.g. Henry ([1990] 2008); Taipale (2009).

26 Al-Saji (2010, p. 18); cf. Gallagher (1986, p. 145ff).

27 Crowell (2012). Crowell renders "Leib" as "animate organism," following Cairns' translation strategy in Cartesian Meditations. I have replaced this by the term "living body" for systematic purposes, explained above.
} 
the naturalistic assumption and clearly disambiguate these notions, [then] (...) the body [with constitutive functions] cannot be the basis of grasping (...) the body [as part of the pre-given world]. The [constituting] body cannot show up at all as an object in the world without losing the very characteristic that makes it what it is. Thus, it cannot serve as the basis for an apperceptive transfer of sense to something that does show up in the world. ${ }^{28}$

The basic worry of equivocation was already voiced by Jacques Derrida in his doctoral thesis, The Problem of Genesis in Husserl's Philosophy (1953-1954). More precisely, the argument was that even if the constituted and constituting aspects of living bodiliness may operate in parallel in concrete phenomenological analyses, Husserl and his followers cannot bring them under the same concepts but actually offer us two accounts, covered by the seemingly unified terminology of Leiblichkeit: "nothing can come to the latter [the constituting] from the former [the constituted]." 29

If this would hold, then we would not merely be dealing with terminological or conceptual difficulties that can be removed by careful language use or heedful definitions, but would be facing fundamental problems of philosophical thinking. On this basis, some critics argue that in order to apply the true principle of Husserl's phenomenology — the principle of unprejudiced thinking-we must turn to other phenomenological approaches, realistic, hermeneutical, fundamental-ontological, existential or dialogical. ${ }^{30}$ Others claim that the whole enterprise needs to be rejected for the establishment of a new "post-phenomenological" approach. ${ }^{31}$

Could the transcendental-phenomenological methods help us with such frustrations and suspicions? What can be gained, if anything, by turning back to Husserl's centennial reflections on embodiment? What, in particular, could be gained by following the methodological guidelines that his Cartesian Meditations offer-a work notorious for its idealistic and solipsistic formulations? Would we fall (back) into a distorted universe in which the only alterity that we can encounter is the alterity of hyletic data supplied to our egoic acts?

In the following, I want to try out this option. I will follow Husserl's guidelines and explicate the sense of the living body by the methods of his Cartesian Meditations. My argument is that paradoxically these old methodological instruments offer a fresh insight into the definitions of living bodiliness distinguished above and allow us to clarify their relations.

\footnotetext{
28 Crowell (2012, pp. 44).

29 Derrida ([1962] 1974, p. 98/98).

30 E.g. Crowell (2013); Waldenfels (2007).

31 E.g. Selinger (ed.) (2009); Oksala (2010).
} 


\section{Constitutional considerations}

Husserl's Cartesian Meditations offers us three methodic tools for the explication and analysis of the sense of living embodiment. These are the transcendental-phenomenological reduction, the eidetic reduction and the abstractive reduction to the so-called sphere of ownness.

The transcendental-phenomenological reduction provides the subject matter of phenomenological inquiries by opening up the field of pure experiences and pure phenomena as their correlates. ${ }^{32}$ The "purity" of this field does not entail exclusion of any experiences or phenomena but merely requires that we interrupt and hold off our judgment concerning their ontic validities. Thus, the task of purification does not imply that we need to abandon all philosophical interest in reality. On the contrary, since most phenomena are given as real, with determinations of materiality, spatiality, temporality and causality, while some appear as illusory or phantasmatic, one important phenomenological task is the clarification of the very sense of reality and its different modalities. In the case of embodiment, this entails, among other tasks, that we study the constitution of material reality, psychic reality, and the realities of animal and human being, as well as the irreality conditioning these realities. ${ }^{33}$

The fact that the transcendental-phenomenological reduction suspends all ontic theses concerning experiences and experienced objectivities is well-known. The different aspects and the coverage of the suspension are worth repeating, however, since they are usually cited only in part. In toto, the task is to suspend one's judgement about the validity of all theories and assumptions of the positive sciences (anthropological, psychological, biological, physiological and physical) as well as the numerous postulates of our everyday practices and emotive lives. At the same time, one is also expected to relinquish one's indebtedness to philosophical doctrines inherited from the tradition as well as contemporary philosophical theories composed for various ends.

According to Husserl, this necessary first step cannot, however, be performed without also suspending the ontic base of all such particular theses and types of theses. This is because all claims about worldly entities, events and processes share a common implicit conviction that concerns the being of the world itself, more precisely, its continuous presence as the unified framework for all possible beings. So, the founding postulate of the world must also be set aside if we want to begin practicing phenomenological inquiries in the radically unprejudiced manner sketched out by Husserl. The world itself cannot be taken as an unquestionable or incontrovertible framework of inquiry but has to be studied as a fundamental phenomenon in need of description and analysis. In Phenomenology of Perception, Merleau-Ponty explains,

Husserl's transcendental is not Kant's and Husserl accuses Kant's philosophy of being 'worldly,' because it makes use of our relation to the world (...) and

\footnotetext{
32 Hua1, p. 60ff./20ff.

33 E.g. Hua4, p. 143ff./151ff.; Hua14, pp. 7-9.
} 
makes the world immanent in the subject, instead of being surprised at the world and conceiving the subject as a process of transcendence towards the world. ${ }^{34}$

The eidetic reduction is needed for the clarification of the senses of selfhood and ownness operative in all experiences of belongingness of bodies to persons, ourselves and others. In so far as we experience some body as our own-whatever that body may be-the task of clarifying the operative sense of ownness falls to us as phenomenologists. Even if such possessive experiences would be merely momentary or passing in our experiential life, even if they would be transitive or radically changing, or would belong to the past and not characterize our present, they are still our experiential possibilities, and in need of clarification as such.

By the core of selfhood- "the eidos of the ego," in his own words-Husserl means those aspects of selfhood that are absolutely necessary for the constitution of the self, any self, be it human or animal, male or female, gendered or trans-gender, abled or disabled, racialized or non-racialized, intelligible or non-intelligible, temporary or continuous, finite or infinite. ${ }^{35}$ So, what we are dealing with here is not a theory of human selfhood or animal subjectivity, but an explication of the necessary aspects of all selfhood imaginable. This implies that the explicative tasks of phenomenological egology must be kept distinct from those of philosophical anthropology and zoology. ${ }^{36}$ While the former clarifies the sense(s) of selfhood, the latter two illuminate the being of humans and animals. All three explications-the egoic, the anthropological and the zoological—are needed for accounting for the special character of human selves.

In Husserl's explication, selfhood involves three structural features: each self operates as an identical pole of experiencing, each relates to some objects or other by egoic acts of intending, and each entails habituated acts and experiences and a style of establishing such "states." 37 Thus, selves are temporally developing centers of intentional life. They come in many different types and are intentionally related to one another in many different registers, perceptual and communicative.

Husserl's insistence on the indispensability of the transcendental and eidetic reductions have caused much controversy, and still do so. In his own account, the former is needed to get access to pure phenomena and the latter is needed to distinguish, phenomenologically, between selfhood and otherness, ownness and alienness. The most peculiar methodological move, however, that his Meditations offer us is the subsequent reduction to the sphere of ownness. This is introduced at the beginning of the fifth Meditation as a special suspension that allows us to study the constitutive relations between the sense of other selves, on the one hand, and that of own living bodiliness, on the other.

\footnotetext{
34 Merleau-Ponty ([1945] 1993, p. viii/xiii).

35 Hua1, p. 65ff./99ff.

36 Hua1, pp. 65ff./26ff., 98-99/62-64; cf. Hua17, p. 238/269-270.

37 Hua1, pp. 99-102/65-68; cf. Hua14, p. 59.
} 
Since my aim here is not to judge Husserl's methods by their complications but to consider them on the basis of their results, I proceed by way of the guideline of Meditations and venture to study how the additional reduction to the sphere of ownness frames the problem of embodiment.

Husserl emphasizes that this methodic step is thematic and abstractive. It operates within the field of transcendentally purified experiences and artificially isolates one of its layers of sense. ${ }^{38}$ So, whereas the transcendental-phenomenological reduction discloses a whole new area of investigation, the subsequent abstractive reduction allows us to focus on specific themes by setting them apart from others. Better formulated, the reduction to the sphere of ownness identifies a layer of sense which operates in all concrete experiences of worldly phenomena and offers it to explicative reflective inquiries.

The main idea is to set aside all sense of other selves and everything that constitutionally depends on such sense. Thus, we disregard all possible others, be they animal, human, personal, collective or other. We also disregard all that depends on such others: their living bodies and the common cultural products that we share with them, from practical utensils and instruments to artworks, religious symbols and scientific objects. Moreover, all philosophical conceptualizations of such selves-as psyches, souls, minds, neural networks, or other-need to be bracketed. Finally, we remove from consideration the senses objective thing and objective world in so far as these objectivities are shared by several experiencing selves. The abstractive reduction thus shuts out all sense of otherness and prevents us from using such senses in our descriptions and analyses of whatever is left to study. ${ }^{39}$ The point is not that we could live in such a reduced "world" but that we must think its possibility in order to understand the composition of our own world, this common world-the only one that exists and can exist for us.

What is left is not a world in any familiar sense of the term; all others are gone and everything that carries the label of their alterity. We find ourselves in an artificial field of perceptually appearing material things without historical, cultural or communal significations. Moreover, things present themselves to us in a peculiar way within this field: They cannot be given from different angles at the same time, since there are no others in our environment, actual or possible, who could occupy alternative positions and open complementary perspectives on things. The material objects that now are given to us disclose themselves by adumbrations but merely in a serial fashion, not simultaneously from different viewpoints.

The next step in Husserl's argumentation is crucial for our understanding of his conception of the sense of living bodies. He points out that in this artificially reduced perceptual environment, one thing - and only one-immediately sets itself apart from all the other things. This is our own living body. It stands out exactly as living, that is as having sensations of different sorts. No other thing can have the sense of living within this artificially isolated environment since all other conscious selves are temporarily reduced, and the sensing ones among them:

38 Hua1, pp. 124-125ff./92-93ff.

39 Hua1, pp. 125-127/96; Hua4, p. 144/151; Husserl ([1939] 1985, pp. 57-58/57-58, cf. 48-50/46-50). 
Among the actually grasped material things belonging to this 'nature,' I then find my own living body as uniquely singled out, namely as the only one of them that is not mere material body but precisely living body, the sole object within my abstract world-stratum to which I, in accordance with experience, ascribe fields of sensings, belonging to it, however, in different manners (field of tactual sensings, warmth-coldness field, and so forth), the only one 'in' which I 'rule and govern' immediately, governing particularly in each of its 'organs. ${ }^{40}$

In light of the different definitions of living bodiliness discussed in Sect. 2 above, Husserl's account here is striking. In the paragraph just quoted, he effectively argues that the minimal sense of bodiliness is that of a sensing thing and that this minimal sense can be constituted completely independently of all other selves. ${ }^{41}$ If this holds, then the living body cannot be a perspective on anything shared by several selves. More precisely, in so far as the living body can appear in an environment in which no subjective perspectives can be distinguished, it cannot be a perspectival disclosure of anything. Thus, even though we may say that our living body "anchors" us to space and "throws" us among things, we must not think that it would originally be given in a perspectival fashion. ${ }^{42}$

This characterization of the living body repeats the main parameters of the more detailed account that Husserl offers in the second volume of Ideas: Our own bodies are originally given to us as peculiar kinds of sensing moving things and primitive spatial objects. However, by introducing the methodic step to the sphere of ownness, the fifth Meditation explicates a crucial factor that remains marginal in the second volume of Ideas: Our bodies appear to us as spatial objects independently of our relations to other selves. To be sure, in this mode of appearing, our living bodies are not full-fledged material things with simultaneous sides or aspects but are considerably reduced and constitutionally imperfect and incomplete. ${ }^{43}$ Still they are not immanent occurrences or systems of such occurrences but are appearing and spatial all the same. Thus, in light of Husserl's methodology, also the other paramount definition discussed above turns out to be partial or premature: in their original givenness, living bodies are not systems of sensings but have thingly spatial determinations. They are not "mere things" nor are they "perfectly constituted" things, but such poverty of thinghood or objectivity does not make them non-spatial occurrences or systems of such occurrences. ${ }^{44}$

If this analysis would hold, then objectivity would not just be part of our givenness to others, as Sartre argues in Being and Nothingness, but would already characterize our fundamental sensory-motor self-relation. We appear to ourselves, independently of all others. The consequences for phenomenological inquiries into

\footnotetext{
40 Hua1, p. 128/97 (translation modified).

41 Cf. Hua14, pp. 6, 281-283.

42 Cf. Zahavi (2003, pp. 101-102); Crowell (2012); Zahavi (2019, pp. 79-80).

43 Hua14, pp. 6-9, 57, 60-63; Hua15, p. 268; cf. Lotz (2007, pp. 88-89); Mattens (2006).

${ }^{44}$ Hua15, pp. 127-128; cf. Hua4, p. 159/167; Hua14, pp. 57, 77; Wehrle (2020).
} 
embodiment are considerable: Whatever bodily experiences or phenomena we may study-be it sickness, suffering, sexuality or mortality-the possibility is open to argue that not all the sense essential to our appearing is determined by the looks of others. $^{45}$

In order to understand how Husserl's conceptualization of the living body frames the three conceptualizations discussed above, we need to look a little closer at his account of the constitution of this body.

Husserl famously contends that both kinaesthetic sensations and touch sensations are necessary for the constitution of the living body as well as a motivational interplay between them. However, he also argues that none of these factors is sufficient, separately or together. What is needed in addition to such sensory systems is the structure of the double-sensation. ${ }^{46}$ This structure is more complicated than is usually suggested: It is not just a combination of kinaesthetic and tactile sensations but forms an elaborate system in which different apperceptive functions and results must be distinguished.

Double sensation is a phenomenon in which two motivationally related systems of kinaesthetic and tactile sensation, both marked by the same self, operate at the same time but are localized as apart from one another. When I grip my left elbow with my right hand, then both the hand and the elbow entertain tactile and kinaesthetic sensations. However, it is also essential to the phenomenon of double sensation that the touch sensations involved can be apprehended in two alternative ways. One and the very same sensation can be apprehended either as my own lived-through sensings or alternatively as presenting qualities or features of external objects. ${ }^{47}$ This possibility is characteristic of all touching. If I press my nose against a window glass in a cold winter morning, I can focus either on the coolness of the glass or else pay attention to the sensation of cold that at the same time spreads and intensifies in my nose. But when I touch my own elbow, instead of a window, then my apprehensive possibilities are doubled. I can alternate between two attentive foci in two separate locations, one in the grasping hand and the other in the grasped elbow. Double sensation is thus double in the sense that it involves two different complexes of two kinds of sensations (kinaesthetic and tactile) and, in addition to this, also two ways of apprehending the touch sensations involved. ${ }^{48}$ Four apprehensive options in toto belong to the phenomenon. Husserl writes,

In the case of one hand touching the other, it is again the same [double apprehension], only more complicated, for we have then two [touch] sensations, and each is apprehendable or experienceable in a double way. ${ }^{49}$

The two hands pictured by Husserl in the second volume of Ideas, and the two lips evoked by Merleau-Ponty in The Visible and the Invisible, do not just operate

\footnotetext{
45 Cf. de Beauvoir ([1949] 1993, pp. 242-243/175); Fanon ([1952] 2008, pp. 83, 106, 180).

46 Hua4, pp. 145-147/153-154.

47 Hua4, p. 147/155; cf. Hua3/1, p. 75/88; Hua5, p. 14.

48 Hua4, pp. 145-146/153-154.

49 Hua4, p. 147/154.
} 
as examples of sensing-moving organs, but epitomize the intentional structure of double-sensation that, in Husserl's analysis, is crucial for the constitution of all living bodiliness, whether human, animal or other. ${ }^{50}$ The necessary role of double sensation is illuminated by Merleau-Ponty by imagining a tactile-kinaesthetic system which, by some "baneful arrangement," could not touch itself or any of its parts. Think, for example, of the egg-shaped creatures pictured by Plato in his Symposium or the isolated brain kept alive in a vat in Hilary Putnam's thought experiment. Such systems, Merleau-Ponty argues, are not "flesh" (chair) enough for the constitution of living bodiliness, despite the synthetic unities of their tactile and kinaesthetic sensations. ${ }^{51}$ What is lacking is the apprehensive structure that constitutes the body as a sensing-sensed duality. In Husserl's own words,

Touching my left hand, I have touch appearances, that is to say, I do not just sense [softness], but I perceive and have appearances of a soft, smooth hand, with such a form. The indicational sensations of movement and the representational sensations of touch which are objectified as features of the thing, 'left hand,' belong in fact to my right hand. But when I touch the left hand I also find in it, too, series of touch-sensations, which are 'localized' in it, though these are not constitutive of properties (...). If I speak of the physical thing, 'left hand,' then I am abstracting from these sensations (...). If I do include them, then it is not that the physical thing is now richer, but instead it becomes body, it senses. ${ }^{52}$

As emphasized already, we can apprehend our tactile sensations in two alternative ways, either as qualities of external things and as our own sensings or affective states. In both cases they are "localized," but differently. The thingly quality is given in the outer object, whereas the sensing is experienced as qualifying an area or zone "in" our own body. We can freely alternate between these two givens by changing the focus of our reflective attention. In double sensation, however, something new comes about: Our sensing does not remain an awareness of an expanding quality. The sensing here, "in" one part of our body, is at the same time experienced "on" or "in" another part of the body as a sensed there. ${ }^{53}$ Let us illuminate this doubling by seizing our left elbow with our right-hand fingers. When our fingers reach our elbow and squeeze it, the sensation of being seized happens in the elbow exactly at the same time that the fingers hit their target and meet a warm soft tissue with a

\footnotetext{
$\overline{50}$ Hua4; Merleau-Ponty (1964b, pp. 177/136-137).

51 Merleau-Ponty (1964a, p. 15/163); cf. Hua4, p.150/156; Moran (2009).

52 Hua4, pp. 144-145/152; cf. Hua5, pp. 11-12, 15; Hua4/5, pp. 362-267.

53 The prepositions "in" and "on" have to be put in quotation marks here, since the original localization of sensations as components of living bodies is crucially different from the localization of intersubjective things in objective space: "joy and sadness are not in the heart in the way in which blood is in the heart; sensations of touch are not on the skin as pieces of organic tissue" (Hua13, p. 115). Another example emphasizes the depth-dimension of the lived body: "For example, I 'sense, feel my hearth.' By pressing on the surface of the lived body in 'the cardiac region,' I simultaneously encounter this feeling of the hearth [Herzgefühl], it becomes stronger, it becomes something modified: It does not belong to the touch surface itself, but relates to it" (Hua4/5, pp. 361, 368).
} 
resistant inner core. Conversely, the sensations of warmness and resistance occur in the fingers exactly when the elbow senses a firm grip from "outside." Moreover, these sensations occur in the intersection or junction of respective egoic movements. The here of our seizing fingers meets the there of our relaxed elbow, and conversely the here of our reposing elbow coincides with the there of the fingers. In this junction, the inner receives an outer appearance and the outer reveals its inner state. ${ }^{54}$ This twofold doubling of sensations is missing when our fingers meet a cold windowpane or a hot oven. It is absent also when we stroke the soft paws of a cat or hold the hands of a friend. We realize of course that others sense our touch but we do not, and cannot, live through their sensings. ${ }^{55}$

In Husserl's analysis, this doubling of sensation is crucial to the explication of the primary sense of living bodiliness. The living body is originally constituted as a dynamic intertwinement of sensings and sensed qualities, internality and externality, subjectivity and objectivity. The constitution of such a phenomenon requires kinaesthetic sensations and touch sensations, but, in addition to these, also a double way of apprehending sensations. Sensations have to be grasped as thingly qualities while, at the same time, remaining given as subjective sensings,

The living body constitutes itself originally in a double way: first it is a physical thing, matter; it has its extension, in which are included its real properties, its color, smoothness, hardness, warmth (...). Secondly, I find on it, and I sense 'on' it and 'in' it: warmth on the back of the hand, coldness in the feet, sensations of touch in the fingertips. ${ }^{56}$

Thus constituted, the living body is a twofold dynamic structure in which the sensing and the sensed are intertwined or interlaced. It is not just a surface on which pure subjectivity encounters its other or a limit that it endlessly approaches without ever crossing over. On the contrary, it is a subjective objectivity that perpetually reestablishes its thinghood by moving and sensing. Our living body is who we are and what we have in the first place, our very being and our primary possession in the world. ${ }^{57}$ It is not all that we are and not all that we have but it is the very condition of our worldly acting and having.

This means that duality of the living body must be kept separate from the opposition of subjectivity and objectivity. But, in addition, the duality of the body must also be distinguished from a third kind of twoness: the layered being of the psychophysical thing, central to the natural sciences and all discourses that build on them. Living bodies, as they are given to us in experience, are not two-layered psychophysical objects, in which the psychic is causally or functionally established on

\footnotetext{
54 Hua4, pp. 150-151/158-159; Hua15, p. 652; cf. Merleau-Ponty (1964a, pp. 16-21/162-163).

55 Husserl famously argues that the other's living body is constituted on the basis of the sense of own living bodiliness by acts of empathetic transfer of sense. For a more detailed account of this constitutional process, see Heinämaa (2018).

56 Hua4, p. 145/153 (translation modified); cf. Hua4/5, pp. 362-366.

57 Cf. Legrand (2011); Slatman (2014); Dolezal (2015, pp. 19-20); Wehrle (2020).
} 
physical reality. Bodies are not connected or combinatory realities but unified beings with thoroughly intentional structures. ${ }^{58}$

The possibility of grasping one's own living body as a two-layered psychophysical thing as well as the possibility of experiencing it as an expressive whole both depend on the givenness of other selves. My body cannot operate as an expressive means for me if others are constitutively absent from my field of experiencing. I may be able to arrange my fingers in the manner that is characteristic of the gestural sign of victory, for example, but in so far as all others are lacking in my experience, this digital formation cannot express anything to anyone. There are no others to whom the gesture could convey a message, and for myself the sign would be redundant since, when I start arranging my fingers, the expressed content is already given and does not need to be conveyed to anybody. ${ }^{59}$ Similarly, I may scratch my head to relieve itching but I cannot do the same to express bewilderment; and I may wrap my arms around my body for warmth but I cannot comfort myself, unless I am able to intend others, actual or possible, real or imaginable.

Also, the sense of the body as a two-layered psychophysical thing depends on the appearance of others. However, its dependence relations are more specific and complicated than those of the expressive gestural body. Whereas the appearance of the gestural body merely depends on the givenness of some communicative others-any such others - the two-layered thing depends on very specific and distinct theoretical activities. ${ }^{60}$ In other words, the two-layered thing is not an experienceable object given in straightforward (ap)perception but is a scientific object that depends, in its being and validity, on the activities of abstraction, idealization and formalization. This theoretical object can be used in the explanation and prediction of the comportments of humans and animals, but it is not an autonomous or primary constitutional formation. On the contrary, it depends on the intersubjective givenness of human and animal bodies as expressive wholes which for their part depend on the subjective givenness of one's own living body as a sensing moving thing. ${ }^{61}$

\section{Conclusion}

I have argued that if we follow the methodological steps distinguished by Husserl, then we can clarify the relations between the different definitions of living bodiliness that we find in contemporary phenomenological literature. These are relations

\footnotetext{
58 Hua4, p. 239/251; Hua13, pp. 86-88; Hua14, pp. 55-63. The term "psychophysical" thus has two different usages: On the one hand it is used in the characterization of the reduced sphere of ownness and on the other hand it is used in the characterization of the natural-scientific universe, shared by the positive sciences of experimental psychology, physiology or biology. These two usages and senses should not be assimilated, since the latter is dependent while the former is independent of intersubjectivity. This assimilation seems to be at the heart of Henry's critique of Husserl's fifth meditation in his Material Phenomenology ([1990] 2008, p. 106ff.).

59 Cf. Hua19/1, pp. 31/187-188.

60 Husserl ([1939] 1985, pp. 155-159/135-138).

61 Hua4, pp. 183-184/193; Hua6, pp. 244-245/297.
} 
of primacy in the order of the sense-constitution. In Husserl's analysis, the constitution of the living body depends on systems of sensations of touch and movement. At the same time, his analysis also makes clear that living bodies are not such systems in any form of immanence. In addition to sensations, the living body also depends on two modes of apprehension in which sensations are objectified in alternative ways. Such apprehensions do not operate as additional perspectives on the body but are essential to its constitution as such. This primary apprehension, Husserl argues, happens independently of all others, actual or possible.

Thus constituted, the living body is a spatial object, a thing, but it is not a fullfledged spatial object or a completely constituted thing given in intersubjective space. For the completion and fullness of its constitution, other subjects are needed. This means that the living body, in its original first-person givenness, is not a perspective on anything that could be observed from other perspectives. It is our very manner or way of being in the world and, as such, it allows us to adopt perspectives in the world. Thus, we "are" our bodies in a fundamental sense. But this is not all that we are.

Funding Open access funding provided by University of Jyväskylä (JYU). Funding was provided by the Academy of Finland, Research Council for Culture and Society.

Open Access This article is licensed under a Creative Commons Attribution 4.0 International License, which permits use, sharing, adaptation, distribution and reproduction in any medium or format, as long as you give appropriate credit to the original author(s) and the source, provide a link to the Creative Commons licence, and indicate if changes were made. The images or other third party material in this article are included in the article's Creative Commons licence, unless indicated otherwise in a credit line to the material. If material is not included in the article's Creative Commons licence and your intended use is not permitted by statutory regulation or exceeds the permitted use, you will need to obtain permission directly from the copyright holder. To view a copy of this licence, visit http://creativecommons.org/licen ses/by/4.0/.

\section{References}

Al-Saji, Alia. 2010. Bodies and sensings: On the uses of Husserlian phenomenology for feminist theory. Continental Philosophy Review 43(1): 13-37.

Behnke, Elisabeth A. [1989] 1996. Edmund Husserl's contribution to phenomenology of the body in Ideas II. In Issues in Husserl's Ideas II, eds. Thomas Nenon and Lester Embree, 135-160. Dordrecht: Kluwer.

Castellini, G., F. Trisolini and V. Ricca. 2014. Psychopathology of eating disorders. Journal of Psychopathology 20: 461-470.

Crowell, Steven. 2012. Transcendental phenomenology and the seductions of naturalism: Subjectivity, consciousness, and meaning. In The Oxford Handbook of Contemporary Phenomenology, ed. Dan Zahavi, 25-47. Oxford: Oxford University Press.

Crowell, Steven. 2013. Normativity and Phenomenology in Husserl and Heidegger. Cambridge: Cambridge University Press.

Dahlberg, Helena and Karin Dahlberg. 2019. Open and reflective life-world research: A third way. Qualitative Inquiry 26: 458-464.

Dahlberg, Karin, Maria Nyström and Nancy Drew. 2001. Reflective Lifeworld Research. Lund: Studentlitteratur.

de Beauvoir, Simone. [1949] 1993. Le deuxième sexe I: les faits et les mythes, Paris: Gallimard. English edition: 1987. The Second Sex (ed. and trans: H.M. Parshley). Harmondsworth: Penguin. 
Derrida, Jacques. [1962] 1974. Introduction. In Edmund Husserl: L'origine de la géométrie. Trans: Jacques Derrida. Paris: PUF. English edition: 1989. Edmund Husserl's “Origin of Geometry": An Introduction (trans: John P. Leavey). Lincoln: University of Nebraska Press.

Dolezal, Luna. 2015. The Body and Shame: Phenomenology, Feminism and the Socially Shaped Body. Lanham, Boulder, New York: Lexington Books.

Englebert, J., V. Follet, and C. Valentiny. 2018. Anorexia nervosa and first-person perspective: Altruism, family system, and bodily experience. Psychopathology 51: 24-30.

Fanon, Franz. [1952] 2008: Black Skin, White Masks. Trans: Charles Lam Markmann. London: Pluto Press.

Friesen, Norm, Carina Henriksson and Tove Saevi. 2012. Hermeneutic Phenomenology in Education: Method and Practice. Rotterdam, Boston, Tapei: Sense Publishers.

Fuchs, Thomas. 2005. Leib, Raum, Person: Entwurf einer phänomenologischen Anthropologie. Stuttgart: Klett-Cotta.

Gaete, María Isabel and Thomas Fuchs. 2016. From body image to emotional bodily experience in eating disorders. Journal of Phenomenological Psychology 47: 17-40.

Gallagher, Shaun. 1986. Hyletic experience and the lived body. Husserl Studies 3(2): 131-166.

Gallagher, Shaun. 2005. How the Body Shapes the Mind. Oxford: Oxford University Press.

Heinämaa, Sara. 2011. The body. In The Routledge Companion to Phenomenology, eds. Sebastian Luft and Søren Overgaard, 222-232. London: Routledge.

Heinämaa, Sara. 2018. Embodiment and bodily becoming. In The Oxford Handbook of the History of Phenomenology, ed. Dan Zahavi, 533-557. Oxford: Oxford University Press.

Henry, Michel. 1975. Philosophy and Phenomenology of the Body. Trans: Girard Etzkorn. The Hague: Martinus Nijhoff.

Henry, Michel. [1990] 2008. Material Phenomenology. Trans: Scott Davidson. New York: Fordham University Press, 1990. Original Phénoménologie Matérielle. Paris: PUF, 1990.

Husserl, Edmund. Hua1. Cartesianische Meditationen und pariser Vorträge, Husserliana I, ed. Stephan Strasser. The Hague: Martinus Nijhoff, 1950. English edition: 1960. Cartesian Meditations (trans: Dorion Cairns). The Hague: Martinus Nijhoff. Originally published in 1931 in French translation, Méditations Cartésiennes, by Emmanuel Levinas and Gabriel Pfeiffer.

Husserl, Edmund. Hua3. Ideen zu einer reinen Phänomenologie und phänomenologischen Philosophie, Erstes Buch: Allgemeine Einführung in die reine Phänomenologie, Husserliana III, edited by Walter Biemel. The Hague: Martinus Nijhoff, 1950. English edition: [1931] 1962. Ideas: General Introduction to a Pure Phenomenology (trans: W.R. Boyce Gibson). New York, London:Collier.

Husserl, Edmund. Hua4. Ideen zu einer reinen Phänomenologie und phänomenologischen Philosophie, Zweites Buch: Phänomenologische Untersuchungen zur Konstitution, Husserliana IV, ed. Marly Biemel. The Hague: Martinus Nijhoff, 1952. English edition: 1993. Ideas Pertaining to a Pure Phenomenology and to a Phenomenological Philosophy, Second Book: Studies in the Phenomenological Constitution (trans: Richard Rojcewicz and André Schuwer). Dordrecht, Boston, London: Kluwer, 1993.

Husserl, Edmund. Hua4/5. Ideen zu einer reinen Phänomenologie und phänomenologischen Philosophie. Zweites Buch: Phänomenologische Untersuchungen zur Konstitution und Wissenschaftstheorie, Husserliana IV/V, ed. Dirk Fonfara. The Hague: Springer, forthcoming.

Husserl, Edmund. 5. Ideen zu einer reinen Phänomenologie und phänomenologischen Philosophie. Drittes Buch: Die Phänomenologie und die Fundamente der Wissenschaft, Husserliana V, ed. Marly Biemel. The Hague: Martinus Nijhoff, 1952.

Husserl, Edmund. Hua6. Die Krisis der europäischen Wissenschaften und die transzendentale Phänomenologie: Eine Einleitung in die phänomenologischen Philosophie, Husserliana VI, ed. Walter Biemel. The Hague: Martinus Nijhoff, 1954. English edition: 1988. The Crisis of European Sciences and Transcendental Phenomenology: An Introduction to Phenomenological Philosophy (trans: David Carr). Evanston, Illinois: Northwestern University.

Husserl, Edmund. Hua13. Zur Phänomenologie der Intersubjektivität: Texte aus dem Nachlass, Erster Teil: 1905-1920, Husserliana XIII, ed. Iso Kern. The Hague: Martinus Nijhoff, 1973.

Husserl, Edmund. Hua14. Zur Phänomenologie der Intersubjektivität: Texte aus dem Nachlass, Zweiter Teil: 1921-1928, Husserliana XIV, ed. Iso Kern. The Hague: Martinus Nijhoff, 1973.

Husserl, Edmund. Hua15. Zur Phänomenologie der Intersubjektivität: Texte aus dem Nachlass, Dritter Teil: 1929-1935, Husserliana XV, ed. Iso Kern. The Hague: Martinus Nijhoff, 1973.

Husserl, Edmund. Hua16. Ding und Raum: Vorlesung 1907, Husserliana XVI, ed. Ulrich Claesges. The Hague: Martinus Nijhoff, 1973. 
Husserl, Edmund. Hua17. Formale und transzendentale Logik: Versuch einer Kritik der logischen Vernunft, Husserliana XVII, ed. Paul Janssen. The Hague: Martinus Nijhoff, 1974. English edition: Formal and Transcendental Logic (trans: Dorion Cairns). The Hague: Martinus Nijhoff, 1969.

Husserl, Edmund. Hua19/1. Logische Untersuchungen, Zweiter Band, I Teil: Untersuchungen zur Phänomenologie und Theorie der Erkenntnis, Husserliana XIX/1, ed. Ursula Panzer. The Hague: Martinus Nijhoff, 1984. English edition: Logical Investigations, Volume 1 (trans: J.N. Findlay). London and New York: Routledge.

Husserl, Edmund. [1939] 1985. Erfahrung und Urteil: Untersuchungen zur Genealogie der Logik, revised and ed. Ludwig Landgrebe. Hamburg: Felix Mayer Verlag. English edition: 1973. Experience and Judgement: Investigations in a Genealogy of Logic (trans: James S. Churchill and Karl Ameriks). Evanston, Illinois: Northwestern University Press.

Johnson, Katherine. 2007. Chaning sex, changing self: Theorizing transition in embodied subjectivity. Men and Masculinities 10(1): 54-70.

Kondelin, Sade. 2014. Dis/orientation of gender and sexuality in transgender embodiment. SQS 1-2: $32-43$.

Leder, Drew. 1990. The Absent Body. Chicago: The University of Chicago Press.

Leder, Drew. 1992. A tale of two bodies: The Cartesian corpse and the lived body. In The Body in Medical Thought and Practice, ed. Drew Leder. Dordrecht: Kluwer.

Legrand, Dorothee. 2011. Phenomenological dimensions of bodily self-consciousness. In The Oxford Handbook of the Self, ed. Shaun Gallagher, 204-227. Oxford: Oxford University Press.

Levinas, Emmanuel. [1930] 1963. Théorie de l'intuition dans la phénoménologique de Husserl. Paris: Vrin. English edition: 1955. The Theory of Intuition in Husserl's Phenomenology (trans: André Orianne). Evanston, Illinois: Northwestern University Press.

Levinas, Emmanuel. [1959] 1998. Intentionality and metaphysics. In Discovering Existence with Husserl. Trans: Richard A. Cohen and Michael B. Smith. Evanston, Illinois: Northwestern University Press, $122-129$.

Lindemann, Gesa. 2010. The lived human body from the perspective of the shared world (Mitwelt). Trans: Millay Hyatt, Journal of Speculative Philosophy 24(3): 275-291.

Lotz, Christian. 2007. From Affectivity to Subjectivity: Husserl's Phenomenology Revisited. New York: Palgrave.

Mattens, Filip. 2006. On the introduction of the concept of the phantom in Ideas II: A case-study in Husserl's theory of constitution. New Yearbook of Phenomenology and Phenomenological Philosophy 7: 83-107.

Merleau-Ponty, Maurice. 1942. La structure du compartment, Paris: PUF. English edition: 2006. The Structure of Behavior (trans: Alden F. Fisher). Pittsburg: Duquesne University Press.

Merleau-Ponty, Maurice. [1945] 1993. Phénoménologie de la perception. Paris: Gallimard. English edition: 1995. Phenomenology of Perception (trans: Colin Smith). London: Routledge.

Merleau-Ponty, Maurice. 1964a. L'Eil et l'esprit, Paris: Gallimard. English edition: 1964. Eye and mind (trans: C. Dallery). In The Primacy of Perception and Other Essays on Phenomenological Psychology, the Philosophy of Art, History and Politics, ed. James M. Edie, 159-190. Evanston, Illinois: Northwestern University Press.

Merleau-Ponty, Maurice. 1964b. Le visible et l'invisible, ed. Claude Lefort. Paris: Gallimard. English edition: 1975. The Visible and the Invisible (trans: Alphonso Lingis). Evanston, Illinois: Northwestern University Press.

Moran, Dermot. 2009. The phenomenology of perception: Charles Taylor and Edmund Husserl. Colloquim 3: 80-104.

Oksala, Johanna. 2010. Feminist Experiences: Foucauldian and Phenomenological Investigations. Evanston, Illinois: Northwestern University Press.

Plessner, Helmunt. 1970. Laughing and Crying: A Study of the Limits of Human Behavior. Evanston, Illinois: Northwestern University Press.

Plessner, Helmunt. 1975. Die Stufen des Organischen und der Mensch. Berlin, New York: Walter de Gruyter.

Salomon, Gayle. 2010. Assuming a Body: Transgender and Rhetorics of Materiality. New York: Columbia University Press.

Sartre, Jean-Paul. [1938] 1995. Esquisse d'une théorie des émotions. Paris: Herrman. English edition: 1976. The Emotions: An Outline of a Theory (trans: Bernhard Frechtman). New York: Citadel, Philosophical Library. 
Sartre, Jean-Paul. [1943] 1998. L'être et le néant: essai d'ontologie phénoménologique. Paris: Gallimard. English edition: 1956. Being and Nothingness: A Phenomenological Essay on Ontology (trans: Hazel E. Barnes). New York: Washington Square.

Seebold, Elmar. (ed.) 2002. Kluge Etymologische Wörterbuch der deutschen Sprache, by Friedrich Kluge, revised 24th edition. Berlin, New York: Walter de Gruyter.

Selinger, Evan, ed. 2009. Postphenomenology: A Critical Companion to Ihde. Albany: SUNY Press.

Slatman, Jenny. 2014. Our Strange Bodies: Philosophical Reflection on Identity and Medical Interventions. Amsterdam: Amsterdam University Press.

Sparrow, Tom. 2015. Plastic Bodies: Rebuilding Sensations after Phenomenology. London: Open Humanities Press.

Svenaeus, Fredrik. 2013. Anorexia nervosa and the body uncanny: A phenomenological approach. Philosophy, Psychiatry, Psychology 20(1): 81-91.

Svenaeus, Fredrik. 2015. The lived body and personal identity: The ontology of exiled body parts. In Bodily Exchanges, Bioethics and Border Crossing: Perspectives on Giving, eds. Erik Malmqvist and Kristin Zeiler, 19-34. Selling and Sharing Bodies: Routledge.

Taipale, Joona. 2009. Incarnate Subjectivity: The Constitutive Significance of Embodiment in Husserlian Phenomenology. Ph.D. Dissertation, University of Helsinki.

Toombs, Kate. 1988. Illness and the paradigm of lived body. Theoretical Medicine 9(2): 201-226.

Waldenfels, Berdhard. 2007. The Question of the Other. Hong Kong: The Chinese University Press.

Wehrle, Maren. 2020. Being a body and having a body: The twofold temporality of embodied intentionality. Phenomenology and the Cognitive Sciences 19:499-521. https://doi.org/10.1007/ s11097-019-09610-z.

Welton, Donn. 1999. Soft, smooth hand: Husserl's phenomenology of the lived-body. In The Body, ed. Donn Welton, 38-56. Malden, MA: Blackwell Publishers.

Zahavi, Dan. 2003. Husserl's Phenomenology. Stanford: Stanford University Press.

Zahavi, Dan. 2019. Phenomenology: The Basics. London: Routledge.

Publisher's Note Springer Nature remains neutral with regard to jurisdictional claims in published maps and institutional affiliations. 